\title{
ボアホールレーダーによる花崗岩岩盤特性調査 一金石鉱山原位置試験場に拈ける調査結果について一
}

\author{
仙波 毅 $^{* 1}$ - 尾方伸久 ${ }^{* 1} \cdot$ 長谷川健 ${ }^{* 1}$ - 岩崎 浩 $^{* 2}$ - 渡辺邦夫*3
}

\section{Characterization of Granitic Rock by means of the Borehore Radar \\ - On the Result of the Measurements at the Kamaishi Mine in-situ Experiment Site-}

Takeshi SEMBA*1, Nobuhisa OGATA*1, Ken HASEGAWA*1, Hiroshi IWASAKI ${ }^{* 2}$ and Kunio WATANABE*3

\begin{abstract}
Key words : ボアホールレーダー borehore radar, クロスホール調査 crosshole measurement, トモグラフィ tomography
\end{abstract}

\begin{abstract}
Power Reactor and Nuclear Fuel Davelopment Corporation (PNC) has been developing techniques of evaluating groundwater flow in granitic rock. In a link of this purpose, PNC introduced the borehole radar system (RAMAC) which was developed by Swedish Nuclear Fuel and Waste Management Co., because it is critical to investigate the spatial extent and dimensions of fracture zones.

This report describes the results of crosshole measurements which were performed with RAMAC system at the Kamaishi Mine in-situ Experiment Site in the northern part of Honsyu Island, Japan.

The results are summarized as follows:

(1) Spatial extent of some low velocity zones and high velocity zones of electromagnetic waves were delineated.

(2) Almost of the seeping points observed by borehole TV lies in the low velocity zones.

(3) The fracture concentrated zones or fracture zones with groundwater recognized by observing the wall of the gallery, which was dug along the borehole used for crosshole measurements, corresponded to the low velocity zones.

These results indicate that the low velocity zone obtained by the borehole radar measurements corresponds with the fracture concentrated zone or fracture zones with groundwater.
\end{abstract}

*1 動力炉 · 核燃料開発事業団 Power Reactor and Nuclear Fuel Development Corporation (PNC)

*2 日鉄鉱業株式会社 Nittetsu Mining Co., Ltd.

*3 埼玉大学工学部 Faculty of Engineering, Saitama University
1. は じめに

結晶質岩盤中では地下水は主に割れ目や割れ目帯を流 れると考えられ，結晶質岩の水理地質特性を評価するた めには, 割れ目や割れ目帯すなわち「水みち」の位置 
・規模・その透水性を把握することが必要不可欠であ る1)。動力炉・核然料開発事業団では，この割れ目や割 れ目帯の位置・規模・その透水性を非破壊で, かつ3 次元的に把握するための調査技術開発の一環として，ス ウェーデン廃棄物管理公社 (SKB) が開発した試錐孔 内用レーダーシステム（RAMAC）を1988年度に導入 し，日本の岩盤における適用試験を実施してきた2),3)。

レーダー法は波長の短い電磁パルスを岩盤内に発信さ せ, 電磁波の速度や減衰特性の変化に着目して, 非破壊 で岩盤の不均質性や不連続面等を調べる手法である4)。 レーダー法で得られる情報は岩盤の電気的な特性に関す るものである。岩盤の電気的な特性はその含水量や水の 電気比抵抗と密接な関係がある。岩盤中に割れ目等が発 達していると, その部分の含水量が多くなり, 含水量が 多くなると電磁波速度は遅く, 減衰は大きくなる。この ような含水量の違いに起因する電磁波の速度や減衰の特 性の変化から, 岩盤の水理地質特性に深く関連している 割れ目や割れ目帯の 3 次元的分布を推定することが可 能となる。

本稿では, 試錐孔内用レーダーシステム（RAMAC） の, 日本の岩盤における適用試験の一環として, 釜石鉱 山原位置試験場内に掘削された試錐孔を用いてクロスホ 一ル調查を行ったので，その結果について報告する。

\section{2. 調 查 位 置}

釜石鉱山は岩手県金石市と遠野市の中間に位置する (図-1)。調査を実施した試錐孔は, 海抜 $575.6 \mathrm{~m}$ に位 置する550 m レベル坑道に掘削されており, 試錐孔は すべて栗橋花崗閃緑岩中に掘削されている（図-2）。 図-3 は調査に使用した試錐孔の位置を示したものであ る。この図に示したように，KD-89坑道から KH-5 号孔

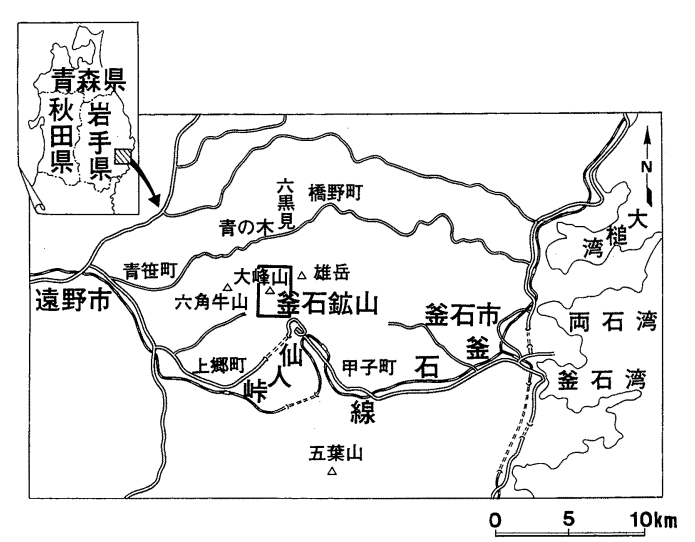

図 -1 釜石鉱山位置図
ふホホ平に掘削されており，KH-5 号孔を中心として，同 一坑道の東側に KH-6 号孔が孔間距離 $12 \mathrm{~m}$ で, 西側の $\mathrm{KD}-88$ 坑道に孔間距離 $13 \mathrm{~m}$ で KH-4 号孔がそれぞれ同 一平面内に水平に掘削されている。また，KH-5 号孔鉛 直上方 $13 \mathrm{~m}$ の KB-89B 試錐座から $\mathrm{KH}-7$ 号孔が水平に 掘削されている。なお, 試錐孔の掘削長は約 $50 \mathrm{~m}$ であ る。

\section{3. 測定および解析法}

\section{1 クロスホール調査の場合の測定法}

クロスホール調査は 2 本以上の試錐孔を利用して行 う。この調査では, 一方の試錐孔にトランスミッタ（発 信プローブ) を，他の試錐孔にレシーバ (受信プローブ) を設置し，トランスミッタを一定深度に固定し，レシー バを一定間隔で移動させ測定を行う。トランスミッタと

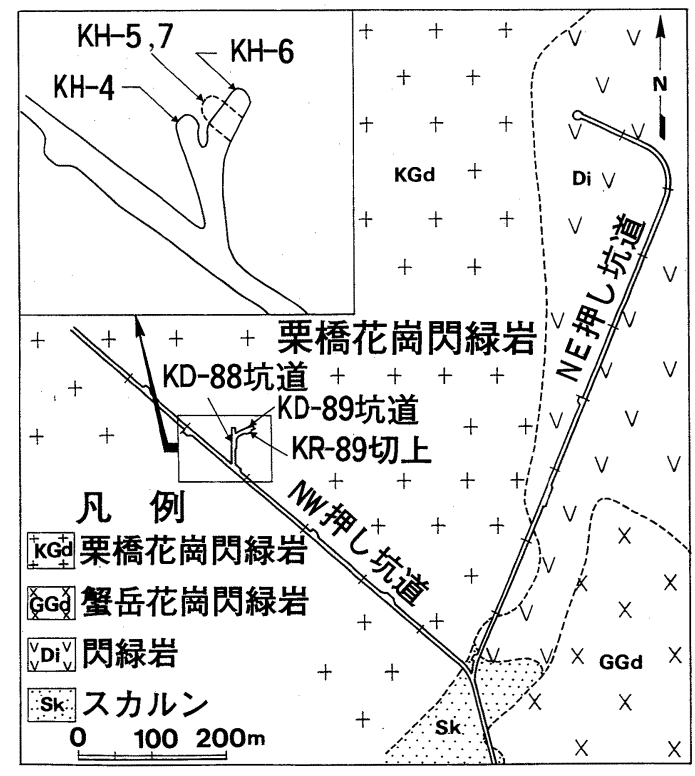

図-2 原位置試験場 $550 \mathrm{~m}$ レベル坑道位置および地質平 面図

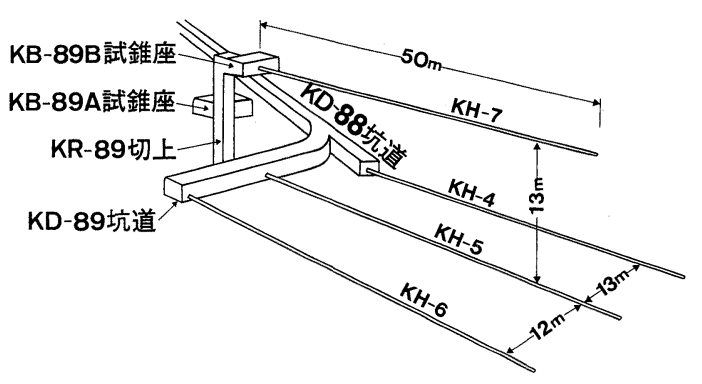

図-3 試錐孔配置詳細図 
レシーバ間の距離が大きくなり, 明瞭な受信信号が得ら れなくなれば，このトランスミッタ深度に扔ける測定を 終了し, トランスミッタを次の点に移動し，同様の測定 を繰り返す（図-4）。今回の調査ではトランスミッタ， レシーバとも $2 \mathrm{~m}$ 間隔で移動させた。測定に用いたア ンテナの中心周波数は $20 \mathrm{MHz}$ および $60 \mathrm{MHz}$ である。 表-1に各測定断面における測定仕様, 測定波線および 解析に用いた波線数をそれぞれ示す。ただし，測定深度 は, 各試錐孔の孔口からの深度で示してある。各プロー ブの 3 次元的位置は, 試錐孔の孔曲りデータを用いて 決定した。

なお，測定は平成 2 年 3 月 21 日から 3 月 25 日に実施 した。

\section{2 解析法}

クロスホール調査で得られたデータを用いて，トモグ ラフィ解析を行った。トモグラフィ解析では, 試錐孔間 の岩盤をいくつかの格子（セル）に分割し, 各セル内の 電磁波のスローネス（slowness；達さ）は一定と仮定 して試錐孔間の岩盤の電磁波のスローネス分布を求め る。ここで, 電磁波のスローネスとは速度の逆数, すな わち, (スローネス) $=1 /$ (速度) である。今回の解析 では, 電磁波の伝播経路をトランスミッタとレシーバを 結んだ直線であると仮定し (反射, 回折等は考えない), CG 法 (Conjugate Gradient method ; 共役勾配法) を 用いて解析を行った5) 7)。

セルサイズについては, OLSSON 等が検討してい る)。これによれば，トランスミッタ・レシーバの移動 間隔と同程度およびその半分程度の大きさとして解析を 行ったところ, 両者の結果は良く整合して抢り, さら に，セルサイズが小さいほうが隣接するセル間の連続が 滑らかで，かつ図が見やすくなると報告されている。そ こで今回は OLSSON 等に倣い，トランスミッタ・レシ 一バの移動間隔の半分の $1 \mathrm{~m} \times 1 \mathrm{~m}$ の正方形セルを用い て解析を行った。各々のセルを通過する波線数の平均は

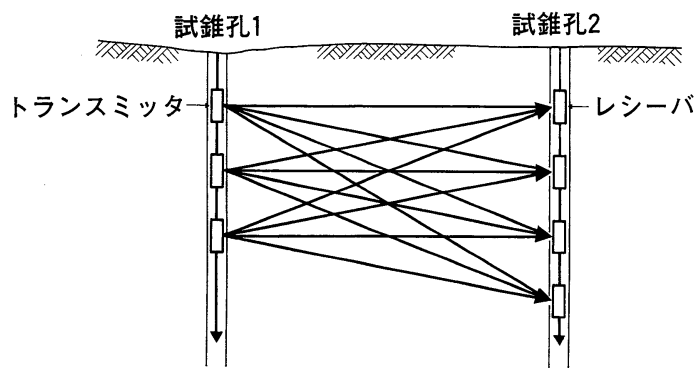

図 -4 クロスホール調査概念図
25であった（図-5)。

トモグラフィ解析結果から得られるスローネスは，基 準值との差（residual slowness ; スローネス残差）で示 した。ここではスローネスの基準値として $9259 \mathrm{ps} / \mathrm{m}$ を用いた。これは，KH-7 と KH-5 号孔間の測定波線の うち，46本の波線を用いて求めた電磁波の平均伝播速 度 $108 \mathrm{~m} / \mu \mathrm{s}$ の逆数である。なお，明らかに測定誤差が 大きいと考えられる波線については，予め測定データか ら除去して解析を行った。

\section{表 -1 調查仕様}

\begin{tabular}{ll}
\hline \multicolumn{2}{c}{$\mathrm{KH}-4 \cdot \mathrm{KH}-5$ 号孔間 } \\
\hline 電磁パルスの中心周波数 & $60 \mathrm{MHz}$ \\
サンプリング周波数 & $632 \mathrm{MHz}$ \\
測定深度 トランスミッタ & $1.20 \mathrm{~m} \sim 45.20 \mathrm{~m}(\mathrm{KH}-5$ 号孔 $)$ \\
& $1.27 \mathrm{~m} \sim 41.27 \mathrm{~m}(\mathrm{KH}-4$ 号孔 $)$ \\
レシーバ & 419 \\
測定波線の総数 & 354 \\
解析に用いた波線の総数 & 354 \\
\hline
\end{tabular}

\begin{tabular}{|c|c|}
\hline \multicolumn{2}{|c|}{$\mathrm{KH}-6 \cdot \mathrm{KH}-5$ 号孔間 } \\
\hline 電磁パルスの中心周波数 & $60 \mathrm{MHz}$ \\
\hline サンプリング周波数 & $632 \mathrm{MHz}$ \\
\hline 測定深度 トランスミッタ & $1.20 \mathrm{~m} \sim 43.20 \mathrm{~m}(\mathrm{KH}-5$ 号孔 $)$ \\
\hline レシーバ & $1.30 \mathrm{~m} \sim 45.30 \mathrm{~m}(\mathrm{KH}-6$ 号孔 $)$ \\
\hline 測定波線の総数 & 439 \\
\hline 解析に用いた波線の総数 & 356 \\
\hline
\end{tabular}

\begin{tabular}{ll}
\hline \multicolumn{2}{c}{$\mathrm{KH}-7 \cdot \mathrm{KH}-5$ 号孔間 } \\
\hline 電磁パルスの中心周波数 & $60 \mathrm{MHz}$ \\
サンプリング周波数 & $632 \mathrm{MHz}$ \\
測定深度 トランスミッタ & $1.20 \mathrm{~m} \sim 45.20 \mathrm{~m}(\mathrm{KH}-5$ 号孔 $)$ \\
& $1.20 \mathrm{~m} \sim 47.20 \mathrm{~m}(\mathrm{KH}-7$ 号孔 $)$ \\
レシーバ & 482 \\
測定波線の総数 & 425 \\
解析に用いた波線の総数 & 425
\end{tabular}

\begin{tabular}{|c|c|}
\hline \multicolumn{2}{|c|}{$\mathrm{KH}-7 \cdot \mathrm{KH}-4$ 号孔間 } \\
\hline 電磁パルスの中心周波数 & $20 \mathrm{MHz}$ \\
\hline サンプリング周波数 & $230 \mathrm{MHz}$ \\
\hline 測定深度 トランスミッタ & $1.27 \mathrm{~m} \sim 41.27 \mathrm{~m}(\mathrm{KH}-4$ 号孔 $)$ \\
\hline レシーバ & $1.20 \mathrm{~m} \sim 47.20 \mathrm{~m}(\mathrm{KH}-7$ 号孔 $)$ \\
\hline 測定波線の総数 & 504 \\
\hline 解析に用いた波線の総数 & 246 \\
\hline \multicolumn{2}{|c|}{$\mathrm{KH}-7 \cdot \mathrm{KH}-6$ 号孔間 } \\
\hline 電磁パルスの中心周波数 & $20 \mathrm{MHz}$ \\
\hline サンプリング周波数 & $230 \mathrm{MHz}$ \\
\hline 測定深度 トランスミッタ & $1.30 \mathrm{~m} \sim 45.30 \mathrm{~m}(\mathrm{KH}-6$ 号孔 $)$ \\
\hline レシーバ & $1.20 \mathrm{~m} \sim 47.20 \mathrm{~m}(\mathrm{KH}-7$ 号孔 $)$ \\
\hline 測定波線の総数 & 552 \\
\hline 解析に用いた波線の総数 & 254 \\
\hline サンプル数* & 512 \\
\hline スタッキング数 & 128 \\
\hline
\end{tabular}

* 1 レコード中のデータ数 

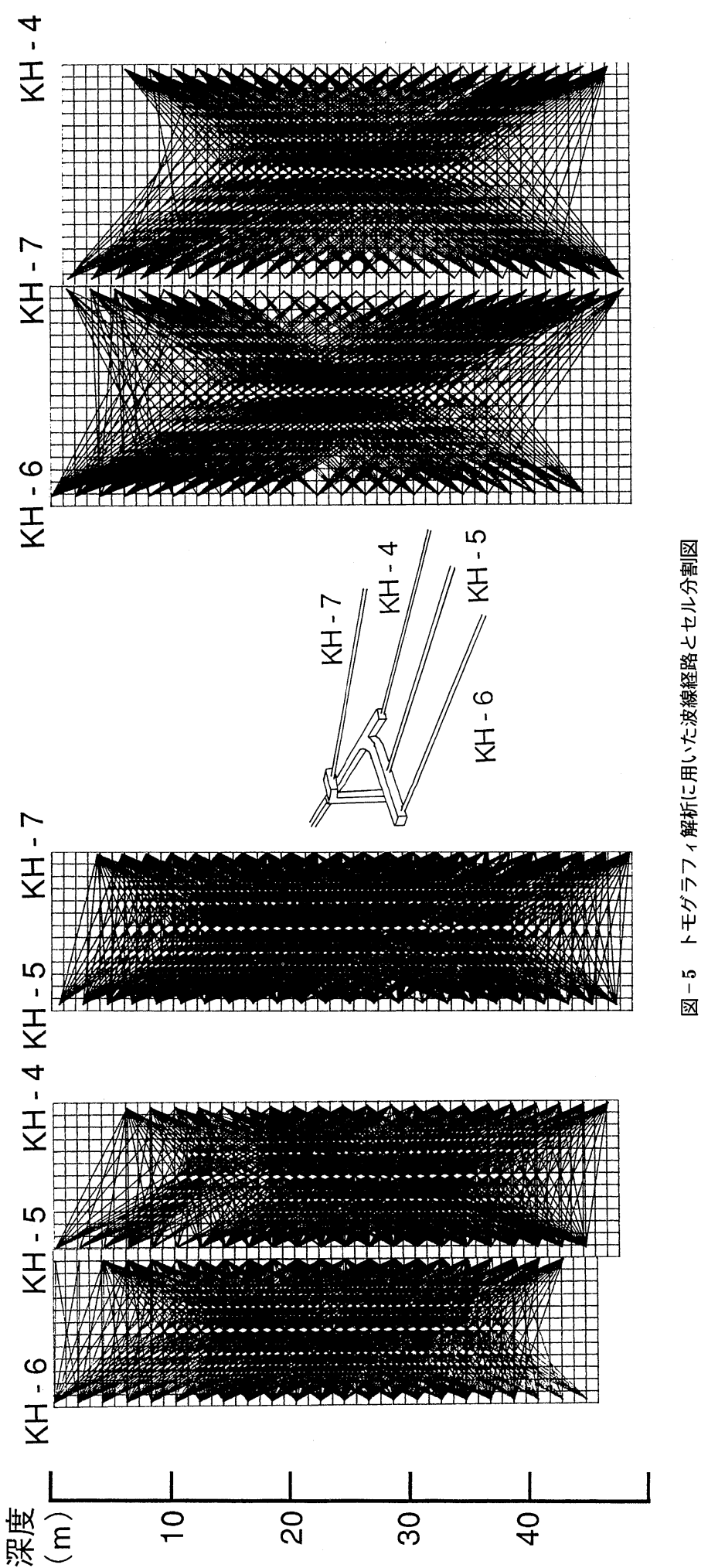

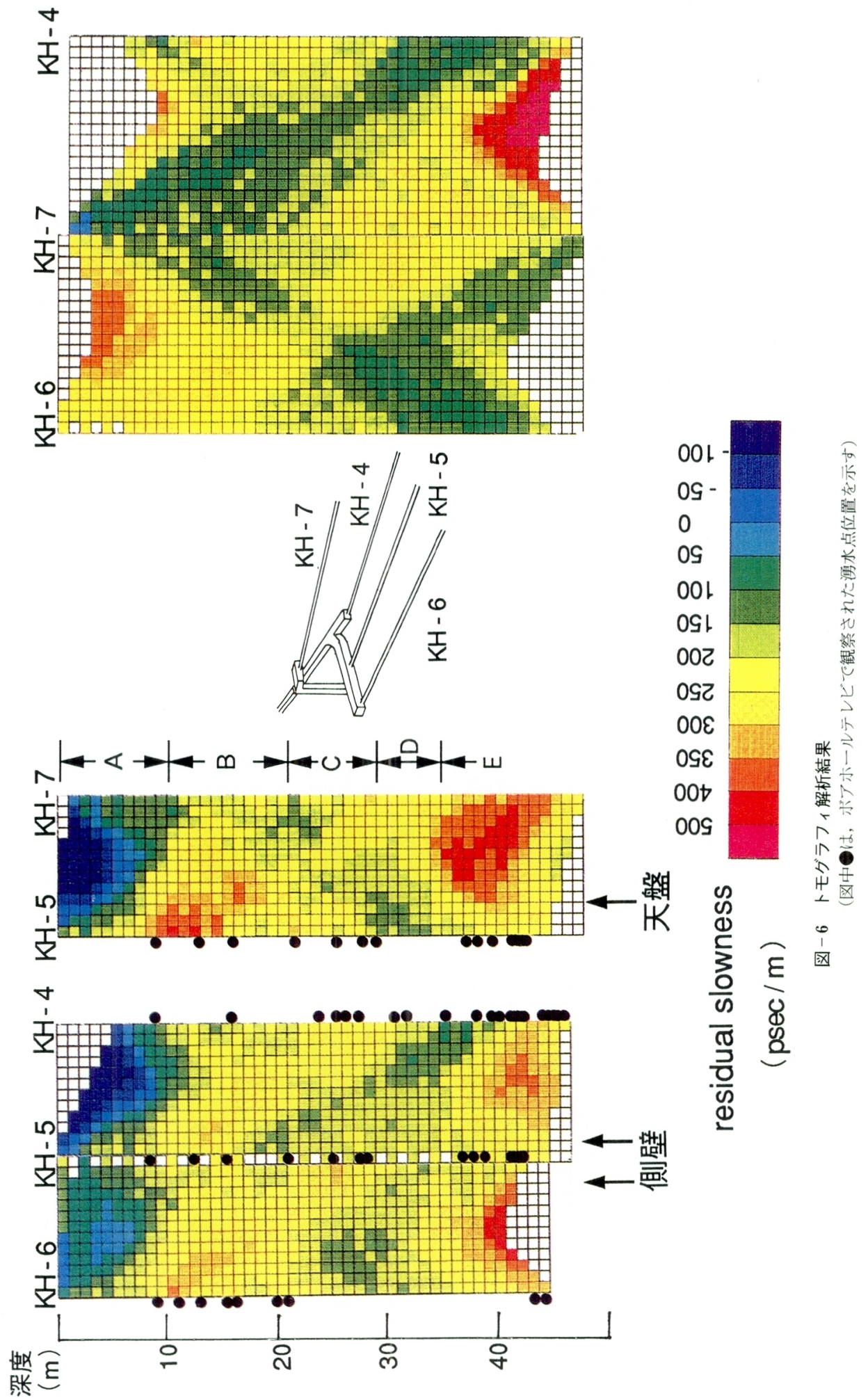


\section{4. 解 析 結 果}

図-6が解析の結果得られたスローネス分布図であ り，綎軸方向に試錐孔深度をとってめる。この図では寒 色系はスローネスが小さいこと（以後, 速度が速いと表 現する）を表し，暖色系はスローネスが大きいこと（以 後, 速度が遅いと表現する）を表しており, 左から, $\mathrm{KH}-6 \cdot \mathrm{KH}-5$ 号孔間断面, KH-4-KH-5 号孔間断面, $\mathrm{KH}-7 \cdot \mathrm{KH}-5$ 号孔間断面, KH-7.KH-6 号孔間断面招上 び KH-7·KH-4 号孔間断面の解析結果である。解析結果 では電磁波速度の速い部分および遅い部分の連続が認め られ，これをまとめると，図-7および図-8のように なる。前者はトモグラフィ解析結果から推定される低速 度（102〜105 m/ $\mu \mathrm{s}$ ）を示す部分の連続（低速度部 1〜 4）を，後者はトモグラフィ解析結果から推定される比 較的高速度（106 $110 \mathrm{~m} / \mu \mathrm{s} ）$ を示す部分（高速度部 1〜2）の連続を示す。ここで, 102 $105 \mathrm{~m} / \mu \mathrm{s}$ はスロ ーネス残差が600 $250 \mathrm{ps} / \mathrm{m}, 106 \sim 110 \mathrm{~m} / \mu \mathrm{s}$ はスロー ネス残差が200〜 - $150 \mathrm{ps} / \mathrm{m}$ の部分である（図-6)。

今回の調查から以下のことが明らかになった。

（1）低速度を示す部分の連続について（図-7）

•低速度部 1

$\mathrm{KH}-7 \cdot \mathrm{KH}-6$ 号孔間断面の深度 $5 \mathrm{~m}$ 付近に見られる低 速度部は, $\mathrm{KH}-7 \cdot \mathrm{KH}-5$ 号孔間断面を通り, $\mathrm{KH}-4 \cdot \mathrm{KH}-$ 5 号孔間断面をかすめ, KH-7·KH-4 号孔間断面へ抜け る。

\section{・低速度部 2}

$\mathrm{KH}-7 \cdot \mathrm{KH}-6$ 号孔間断面の深度 $10 \mathrm{~m}$ 付近に見られる 低速度部は，KH-6-KH-5 号孔間断面を通り，KH$7 \cdot \mathrm{KH}-5$ 号孔間断面に抜けるが，KH-4·KH-5 号孔間断 面においては KH-4 号孔に向かっては延びていかない。

・低速度部 3

$\mathrm{KH}-7 \cdot \mathrm{KH}-4$ 号孔間断面の深度 $7 \mathrm{~m}$ 付近に見られる低 速度部は, KH-7·KH-5 号孔間断面を通り, KH-6·KH5 号孔間断面に抜ける。

- 低速度部 4

$\mathrm{KH}-7 \cdot \mathrm{KH}-4$ 号孔間断面の深度 $37 \mathrm{~m}$ 付近に見られる 低速度部は, $\mathrm{KH}-7 \cdot \mathrm{KH}-5$ 号孔間断面を通り, KH6-KH-5 号孔間断面に抜ける。

（2）比較的高速度を示す部分の連続について（図-8） •高速度部 1

$\mathrm{KH}-7$ 号孔孔口付近から KH-4, 5, 6 を含む断面の深度 $30 \mathrm{~m}$ 付近へ抜けるように, 此較的高速度を示す部分が 連続している（トモグラフィ解析結果ではある厚みをも っているが，ここでは便宜上平面として図示した)。こ

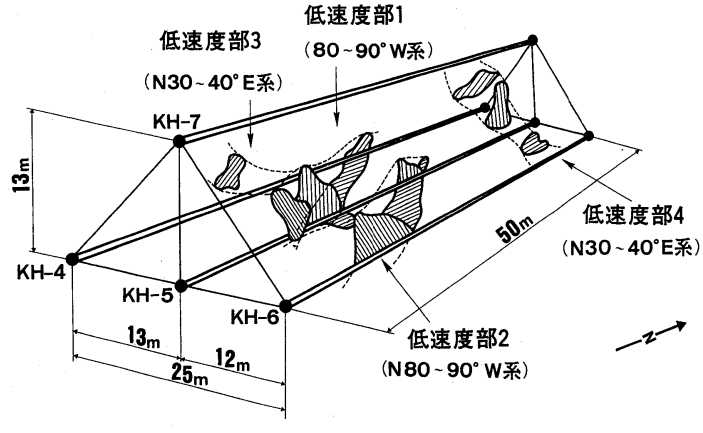

図－7トモグラフィ解析結果から推定される低速度部 (102 105 m/ $\mu \mathrm{s})$ の 3 次元的連続

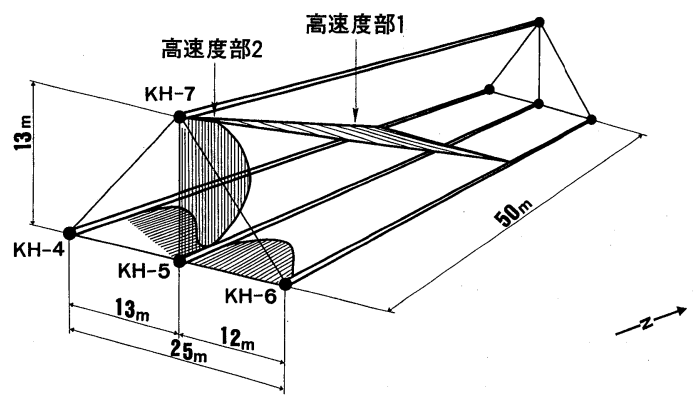

図 -8 トモグラフィ解析結果から推定される高速度部 $(106 \sim 110 \mathrm{~m} / \mu \mathrm{s})$ の 3 次元的連続

の部分の走行は $\mathrm{NE}$ 系, 傾斜は NW 系である。

・高速度部 2

$\mathrm{KH}-4 \cdot \mathrm{KH}-5$ 号孔間断面, KH-6 KH-5 号孔間断面招 よび KH-7·KH-5 号孔間断面の孔口付近に比較的高速度 を示す部分が認められる。この高速度部は, $\mathrm{KH}-7 \cdot \mathrm{KH}-$ 4 号孔間断面拈よび KH-7·KH-6 号孔間断面へは連続し ていない。

この高速度部は坑道の開放面に接しているため, 空気 中を伝播してきた電磁波を誤って読み取ってしまい, 結 果として孔口付近の電磁波速度が実際よりも速く解析さ れたのではないかということが懸念された。そこで， KH-6-KH-5 号孔間断面の坑道の開放面近くで得られた データにより電磁波速度を求めた結果, $109 \mathrm{~m} / \mu \mathrm{s}$ の值 を得た。これは, 空気中を伝播する電磁波速度約 300 $\mathrm{m} / \mu \mathrm{s}$ の約 3 分の 1 に当ることから, 空気中を伝播した 電磁波を誤って読み取ったとは考えられず，この高速度 部は岩盤の状況を反映しているものと考えられる。

\section{5. 考察}

岩盤中を伝播する電磁波の速度 $V_{\mathrm{p}}$ は, 真空中を伝播 
する電磁波の速度を $V_{\mathrm{c}}(=229.8 \mathrm{~m} / \mu \mathrm{s})$, 岩盤の比誘電 率を $\varepsilon_{\mathrm{r}}$ とすると,

$$
V_{\mathrm{p}}=V_{\mathrm{c}} / \sqrt{\varepsilon}_{\mathrm{r}}
$$

で表される。上式に示すように，岩盤中を伝播する電磁 波の速度は岩盤の比誘電率によって決定される。岩盤の マトリックス部の比誘電率は一般的に 5〜10であるのに 対し，水の比誘電率は約 80 と非常に大きな值をとるた め8), 岩盤の比誘電率は岩盤中の含水量に大きな影響を 受ける。すなわち, 空隙率が大きくなったり，割れ目が 発達して岩盤中の含水量が多くなれば，岩盤の比誘電率 が大きくなるため電磁波の速度は遅くなる。したがっ て, 前章で述べたトモグラフィ解析結果で確認された電 磁波速度が遅い部分は含水量が多い部分であると考えら れる。また，電磁波速度が速い部分は岩盤中に割れ目等 が発達していないために含水量が少ない部分であるか， あるいは割れ目等が発達していてもその含水量が少ない 部分であると考えられる。

$\mathrm{KH}-4,5,6,7$ 号孔においてはボアホールテレビによ り孔内の割れ目観察が行われている。この結果, 割れ目 の卓越方向として $\mathrm{N} 30 \sim 40^{\circ} \mathrm{E}$ 系と $\mathrm{N} 80 \sim 90^{\circ} \mathrm{W}$ 系の 2 方向が確認されたが，トモグラフィ解析結果から推定し た上記低速度部 1〜4の連続のうち，1 と 2 は N80〜 $90^{\circ} \mathrm{W}$ 系, 3 と 4 が $\mathrm{N} 30 \sim 40^{\circ} \mathrm{E}$ 系と読み取れ，両結果 は整合している。また, 試錐孔 KH-4, 5, 6 号孔では, 湧水割れ目の位置がボアホールテレビにより確認されて いる。図-6 中に示した・が涌水割れ目の位置であり， 涌水割れ目の位置と電磁波速度の遅い部分の位置は良く 一致している。先にも述べたように，電磁波速度の遅い 部分は含水量の多い部分であると考えられるので, 電磁 波の遅い部分は湧水割れ目を含む割れ目帯であると考え られ，先に推定した電磁波の低速度部の 3 次元的連続 （図-7 参照）は，涌水割れ目を含む割れ目帯の連続で あると推定される。

\section{6. 調查終了後に掘削された坑道壁面で観察され た割れ目との比較}

この試験場では試錐孔を利用した調査終了後, KH-5 号孔に沿って水平坑道（KD-90坑道深度約50 m) が掘 削された（図-9）。この坑道壁面における割れ目分布 状況を調べることにより，試錐孔内の観察結果だけでは なく，さらに広範囲の割れ目とトモグラフィ解析結果と の対比が可能となった。

図-10に KD-90坑道における割れ目観察結果を示す。 この図は坑道天盤を中心とした展開図となっている。坑 道の天盤の位置は $\mathrm{KH}-7 \cdot \mathrm{KH}-5$ 号孔間断面においては,

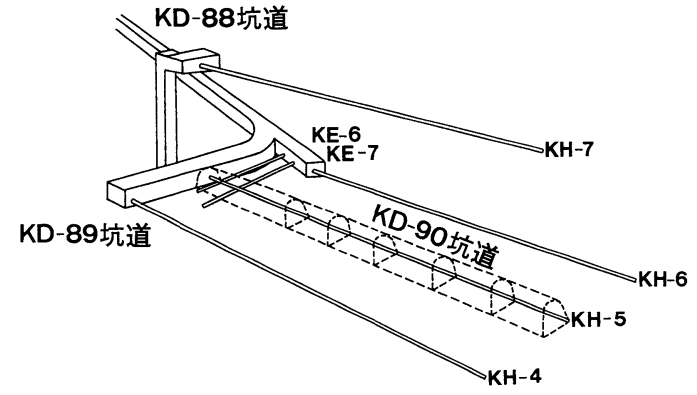

図-9 KD-90坑道および KE-6, KE-7 号孔の位置図

KH-5 号孔から KH-7 号孔に向かって 3 番目のセルに相 当する。また坑道壁面の位置は, KH-4·KH-5 号孔間断 面では KH-5 号孔から KH-4 号孔に向かって 2 番目の セルに相当し，KH-6·KH-5 号孔間断面では KH-5 号孔 から KH-6 号孔に向かってやはり 2 番目のセルに相当 する (図-6 参照)。トモグラフィ解析結果と坑道壁面 で観察された割れ目とを定性的に対比するに当り，坑道 天盤で観察された割れ目の集中度合いにより，A〜Eの 5 つのゾーンに分割した。各ゾーンとトモグラフィ解析 結果とを比較した結果について以下に示す。

(1) ゾーン A $(0 \mathrm{~m} \sim 10 \mathrm{~m})$

このゾーンは全体的に割れ目の密度が低く, 割れ目充 填鉱物としては石英, 方解石, 濁沸石, 束沸石, ブドウ 石等が認められる。割れ目に伴う変質は少なく，天盤か らの滴水はほとんど認められない。坑道壁面においては 特に東側の側壁で多数の涌水点が認められたが, 涌水量 はごくわずかであった。

トモグラフィ解析結果では, KH-4·KH-5 号孔間, $\mathrm{KH}-6 \cdot \mathrm{KH}-5$ 号孔間および KH-7·KH-5 号孔間の各断面 でこのゾーンで電磁波の速度が速くなっているが，これ は上記のように, 割れ目の発達が少ないことと対応して いるものと考えられるが，ここは坑道の開放面側である ため, 坑道壁面からの水分の蒸発により岩盤内の水分量 が減少している可能性もある。

トモグラフィ解析結果では，KH-5 号孔を含む水平面 内で KH-6 号孔方向と比較して，KH-4 号孔方向が電磁 波の速度が速くなっている。この部分では以前に KD88坑道から 2 本の試錐孔（KE-6 および KE-7 号孔，孔 長はそれぞれ $15 \mathrm{~m} ）$ が KH-5 号孔と直行する方向に掘 削されていた（図 -9 参照）。これら 2 本の試錐孔では 掘削直後は多量の湧水が認められたが，その後涌水量は 漸次減少しクロスホール調査時点では湧水はほとんど観 察されなかった。つまり，この 2 本の試錐孔が新たな 水みちとなり, 試錐孔周辺岩盤の水を $\mathrm{KH}-4$ 号孔側から 


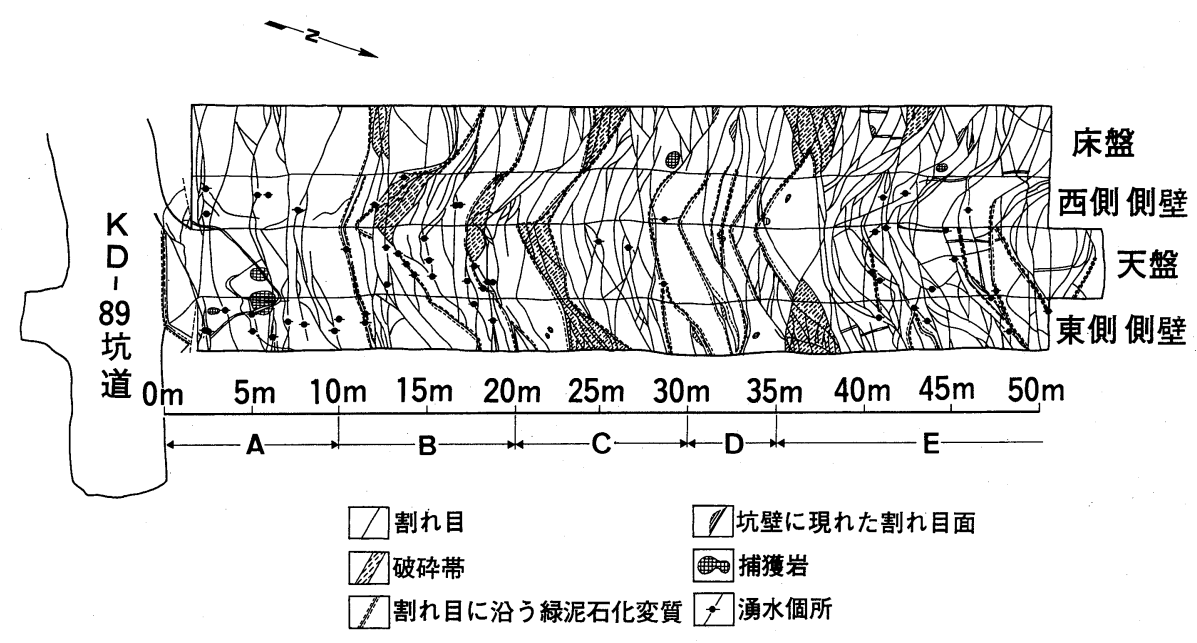

図一-10 KD-90坑道における壁面観察結果

多く排水する形になり，岩盤の乾燥が進んだため，KH4 号孔側の電磁波速度が KH-5 号孔側の電磁波速度より も速くなったものと考えられる。

(2) ゾーン B $(10 \mathrm{~m} \sim 20 \mathrm{~m})$ 〜ゾーンC $(20 \mathrm{~m} \sim 30 \mathrm{~m})$

このゾーンは割れ目密度が高く破碎帯も認められる。 割れ目充填鉱物としては，石英，方解石，濁沸石，束沸 石, ブドウ石等が基本的に認められ，他に緑レン石, 緑 泥石等も多く認められる。また，割れ目に伴う変質も発 達する。ゾーンBにおいては天盤および側壁において 多数の流水・滴水箇所が認められる。

トモグラフィ解析結果では, KH-4·KH-5 号孔間, $\mathrm{KH}-6 \cdot \mathrm{KH}-5$ 号孔間および KH-7·KH-5 号孔間の各断面 とも低速度部が認められる。特にゾーン B の天盤の位 置には電磁波速度が非常に遅い部分が解析されており， 割れ目観察結果と良い対応を示している。またゾーン B では破碎帯は天盤から西方向に延びているが，この部 分では電磁波速度は KH-6 号孔側（東側方向）よりも KH-4 号孔側（西側方向）で遅くなっている。逆に，ゾ ーンCでは破碎帯は天盤から東方向に延びているが， この部分では電磁波速度は KH-4 号孔側（西側方向）よ りも KH-6 号孔側（東側方向）で遅くなっており，トモ グラフィ解析結果と割れ目観察結果はやはり良い対応を 示している。

( 3 ) ゾーン $\mathrm{D}(30 \mathrm{~m} \sim 35 \mathrm{~m})$

このゾーンの割れ目密度はゾーン A よりは若干高い が，ゾーン B C よりは低くなっている。割れ目充填鉱
物はゾーン B C とほぼ同様で, 割れ目に伴う変質はゾ ーン B C と比較して少ないが発達している。また，こ の区間では坑道天盤および側壁からの滴水はほとんど観 察されない。

トモグラフィ解析結果では, KH-4·KH-5 号孔間, $\mathrm{KH}-6 \cdot \mathrm{KH}-5$ 号孔間打よび KH-7.KH-5 号孔間の各断面 とも電磁波速度はゾーン $\mathrm{B} \sim \mathrm{C}$ よりも速いが，ゾーン Aよりは遅い中間の速さを示している。

(4) ゾーン $\mathrm{E}(35 \mathrm{~m} \sim)$

このゾーンは割れ目密度が最も高く,ゾーン B C 同様に破砕帯も発達している。割れ目充填鉱物はゾーン $\mathrm{B} \sim \mathrm{C}$ と同様である。割れ目に伴う变質はゾーン B C に次いで多く発達する。坑道天盤および側壁からの流 水, 滴水箇所および涌水量は他のどのゾーンよりも多く 観察されている。

トモグラフィ解析結果では, KH-4·KH-5 号孔間, $\mathrm{KH}-6 \cdot \mathrm{KH}-5$ 号孔間および KH-7.KH-5 号孔間の各断面 ともゾーン B C と比較して電磁波の速度が羊くなって おり, 坑道天盤および側壁からの流水, 滴水量が他のど のゾーンよりも多いことと良く対応している。

さらに, KH-7·KH-5 号孔間断面には他の断面と比較 してょり低速度を示す部分があり，天盤方向に湧水割れ 目を含む割れ目帯が発達しているものと考えられる。

以上示したように, 坑道壁面観察の結果, 岩盤の含水 量が多いと考えられる部分とトモグラフィ解析の結果得 
られた電磁波速度の低速度部はメートルオーダーで非常 に良い対応を示し, 電磁波の低速度部が涌水割れ目を含 む割れ目帯の連続であるという推定の妥当性が確認され た。

\section{7. よ め}

釜石鉱山原位置試験場内に掘削された試錐孔を利用し てレーダー法クロスホール調査を行い，そのデータを用 いたトモグラフィ解析結果と試錐孔および坑道側壁面観 察結果を比較した結果, 以下のことが明らかになった。 （1）トモグラフィ解析結果により岩盤内の電磁波速度 の低速度部および高速度部の 3 次元的連続性を推定 することができた。

（2）トモグラフィ解析結果で把握できた電磁波速度の 低速度部は湧水割れ目を含む割れ目帯の集中している 所であり，低速度部の 3 次元的連続は湧水割れ目を 含む割れ目帯の連続であるという推定の妥当性が確認 された。このことは，レーダー法クロスホール調査は ボーリングや坑道調査と併用することにより，割れ目 帯や破砕帯の 3 次元的調查に効果を発揮することを 示している。

以上, 本稿において, クロスホール調查で得られたデ 一タをトモグラフィ解析することにより岩盤内の含水状 況を定性的に把握できることを示したが，岩盤の空隙率 とその誘電率の関係を明らかにすることにより，（1） 式を用いて電磁波速度から直接岩盤の空隙率を推定でき るものと考えられる。そこで今後は, トモグラフィ解析 結果から岩盤の空隙率分布を求め, 岩盤内の含水量を定 量的に把握する手法を構築し, その結果および透水試
験，地質記載等により岩盤の透水性を 3 次元的に評価 するための手法を開発していく予定である。

\section{参 考 文 献}

1）渡辺邦夫, 柳沢孝一, PUSCH, R., 佐久間秀樹, 藍沢稔幸, 山本肇, 神田信之 (1990) : 蒸発量計測によるトンネル壁 面からの湧水量の測定(その 2) 一現場計測—, 応用地質, 31巻, 1 号, pp. 1-11.

2）佐久間秀樹，坪田浩二（1988）：土岐花崗岩における RAMAC システムの適用試験について, 物理探査学会第78 回学術講演会講演論文集, pp. 305-309.

3）仙波毅, 尾方伸久, 坪田浩二, 大沢英昭（1989）：ボアホ ールレーダの適用例（特に花崗岩に対する RAMACの適 用), 地下電磁計測ワークショップ一地中探査レーダ, ボ アホールレーダの現状と展望一論文集, pp. 66-70.

4) OLSSON, O., FALK, L., FORSLAND, O., LUNDMARK, L., SANDBERG, E. (1987): Crosshole InvestigationsResults from Borehole Radar Investigations, Stripa Project TR 87-11, SKB, Stockholm, Sweden

5) IVANSSON, S., (1984): Crosshole investigationsTomography and its application to crosshole seismic measurements, Stripa Project TR 84-08, SKB, Stockholm, Sweden

6) 坪田浩二, 則竹和光, 伊東慎司, 落合竜夫 (1989): Getomography における再構成手法評価（その1）, 物理探 查学会第79回学術講演会講演論文集, pp. 49-54.

7) 坪田浩二, 則竹和光, 伊東慎司, 落合竜夫 (1990): Geotomographyにおける再構成手法評価（その 2 ), 物理探 查学会第80回学術講演会講演論文集, pp. 36-41.

8) CARMICHAEL, R. S., (1989): Practical Handbook of Physical Properties of Rocks and Minerals, CRC Press, Inc.

（1991年 8 月 15 受付，1991年11月30日受理） 